\author{
AdAm R. BARTNICKI \\ Karolina Ferreira Fernandes \\ Uniwersytet w Białymstoku
}

\title{
NOWE TECHNOLOGIE INFORMACYJNE A SFERA PUBLICZNA
}

\section{Wstęp}

Ostatnie dwie dekady to ogromny, w swojej istocie rewolucyjny, rozwój nowych technologii informacyjnych - a przede wszystkim Internetu, który gruntownie zmienia życie polityczne, gospodarcze i społeczne oraz tworzy nowe obszary bezpieczeństwa osobistego i państwa. Rozwój Internetu wymaga przedefiniowania wielu pojęć, w tym „sfery publicznej”. Okazuje się, że zachodzące w społeczeństwie zmiany wynikają obecnie nie tylko z przemian politycznych czy gospodarczych, ale przede wszystkim są skutkiem pojawienia się powszechnego i nielimitowanego dostępu do informacji oraz sieciowych platform wymiany poglądów, opinii oraz idei. Internet zmienia jednostkę, społeczeństwo, państwo. Wpływa na sposób odbioru otaczającej rzeczywistości, gusta, preferencje, poglądy. Dzięki Internetowi otaczający świat staje się bliższy i bardziej zrozumiały, chociaż przez to często również groźniejszy. Nowe technologie informacyjne gruntownie przebudowują współczesną kulturę polityczną. Wymuszają większy stopień jawności i demokratyzacji państwa. W reżimach represyjnych dają namiastkę wolności. Umożliwiają walkę z systemem. Opierając się na Internecie - który jest dziś podstawową platformą poszukiwania i wymiany informacji - funkcjonuje społeczeństwo obywatelskie.

Przenoszenie społeczeństwa i państwowości do sieci przynosi wiele bezpośrednich korzyści, ale również wiele poważnych zagrożeń. Stwierdzenie, że pozytywne i negatywne konsekwencje nowych technologii informacyjnych wzajemnie się neutralizują byłoby dziś nadużyciem - o czym przekonamy się zapewne w przyszłości. Konieczne jest jednak zwrócenie uwagi na występujące już problemy i zagrożenia, których skala rośnie wraz z ekspansją Internetu. W tym kontekście należy wspomnieć o stopniowym 
załamywaniu się tradycyjnych regulatorów życia społecznego i nierozerwalnie związanym z tym zjawiskiem anomii, postępującej atomizacji społecznej, ucieczce w świat sieciowej fikcji, swoistej digitalizacji jednostek, kryzysie tradycyjnych relacji międzyludzkich. Internet to obecnie także środowisko stosunkowo prostej manipulacji, propagandy a także zjawisk przestępczych czy cyberterroryzmu.

\section{Nowe technologie informacyjne i sfera publiczna}

Celem naszego artykułu jest opisanie współczesnej sfery publicznej w przestrzeni wirtualnej. By to uczynić na początku swoich rozważań ustalimy ramy pojęcia sfera publiczna i krótki rys historyczny XX-wiecznej teorii na jej temat. Sfera publiczna jest obszarem dyskursu politycznego i wymiany poglądów w nowoczesnym społeczeństwie demokratycznym. Debata na temat dialogu społecznego ożywiona została w Europie Zachodniej po II wojnie światowej głównie przez Hannę Arendt i Karla Poppera, a w latach następnych przez Jurgena Habermasa i Ralfa Dahrendorfa. Filozofia Arendt i Poppera kształtuje się po wstrząsających przeżyciach totalitarnych. Ewolucja tego pojęcia po II wojnie światowej silnie zakorzeniona jest w ideach równości, poszanowania praw jednostki i wspierania idei tolerancji. Olbrzymi strach przed władzą skupioną w rękach grupy rządzącej lub jednostki naturalnie doprowadza myślicieli do wniosku, iż władza powinna być jak najmocniej rozproszona. Sfera publiczna staje się głównym narzędziem kontroli władzy i gwarantem wolności jednostki. Do podobnych wniosków dochodzą o dwadzieścia lat młodsi myśliciele Jurgen Habermas i Ralf Dahrendorf, dla których sfera publiczna stała się remedium na doświadczenia wojenne. Wszystkich autorów łączy szczególna wnikliwa analiza sfery publicznej tworząca nowy nurt w myśli społecznej, a zarazem wiele czerpiąca z dorobku minionych epok, zwłaszcza starożytnych Greków. Nowa hybryda idei stawia na piedestale obywateli, jednocześnie lokując ich w zupełnie nowym środowisku społeczno-politycznym. Niebywały fenomen stanowi owe połączenie i liczne pomysły na to jak ów zamysł zrealizować.

Koncepcje te są niezmiernie inspirujące po dzień dzisiejszy. Szczególnie popularne stały się wraz z rozwojem idei demokracji partycypacyjnej na Zachodzie, opartej na dialogu społecznym, która powstała w odpowiedzi na wiele problemów i barier w funkcjonowaniu demokracji parlamentarnej. 
Nie zapomniano o nich również po wschodniej stronie żelaznej kurtyny, gdzie opozycja tworzyła ową sferę w podziemiach, a potem stopniowo wyłaniała się na powierzchnie. Manuel Castells [2010: 63] pisze, że z punktu widzenia teorii społecznych, przestrzeń internetowa jest materialnym wsparciem współczesnych praktyk społecznych. W swojej pracy chcemy udowodnić, że wiele praktyk społecznych, w tym dialog społeczny, diametralnie zmienił się na skutek rozwoju Internetu. Aktualny poziom rozwoju wirtualnej rzeczywistości pozwala bez wahania stwierdzić, że jest on znaczącym segmentem dzisiejszej sfery publicznej. Hannah Arendt [2010: 73] definiując sferę publiczną podkreśla, że wszystko co pojawia się publicznie, może być widoczne i słyszane przez każdego i ma najszerszy z możliwych krąg odbiorców. W tym kontekście nowe media: radio, prasa, telewizja spełniają w zasadniczej mierze ten warunek. Drugim ważnym elementem sfery publicznej jest wspólnotowość. Oznacza ona segment wspólny nam wszystkim i różny od posiadanego w nim przez nas prywatnego miejsca. Sfera publiczna jest zatem miejscem wspólnych działań wykraczających poza sferę prywatnych interesów. W tym kontekście można potraktować Internet jako globalną arenę publiczną. Dopiero to medium daje możliwość tworzenia i rozpowszechniania informacji, kreowania wirtualnych sytuacji społecznych i tworzeniu interakcji i więzi z innymi odbiorcami. Drugim argumentem na rzecz uznania Internetu za segment sfery publicznej, może być teza Habermasa, głosząca, że sfera publiczna jest to dziedzina ludzkiej aktywności społecznej, w której formuje się opinia publiczna. To obszar, na którym ludzie mogą w nieskrępowany i wolny sposób dyskutować na tematy ważne społecznie i przez tę dyskusję wywierać wpływ na poczynania polityków. Może być ona instytucją monitorowania władzy oraz obszarem, w którym jednostki zbierają się po to, aby przedyskutować ważne dla ogółu społeczeństwa problemy.

Ewolucja sfery społecznej $\mathrm{w}$ Internecie przebiegała stopniowo. $\mathrm{Na}$ początku przejawiała się jedynie w zamieszczaniu postów pod artykułami prasowymi i uczestniczeniem w grupach dyskusyjnych, jednak wraz $\mathrm{z}$ rozwojem nowych technologii, mobilnym Internetem, powstaniem wielu portali społecznościowych i narzędzi komunikacji debata zyskała bardzo szeroki zasięg. Na początku wolny i kosztowy Internet, obecnie szybki i tani, powoli obejmuje swym zasięgiem ludzi na całym globie, o co pieczołowicie troszczą się same koncerny IT, jak i konsumenci, którzy doceniają walory osiągnięć technicznych. 


\section{Źródła aktywizmu internetowego}

Coraz szybszy i tańszy Internet jest atrakcyjny zarówno dla indywidualnych aktorów społecznych, jak i grup i instytucji. Sieć pozwala na szybki kontakt $\mathrm{z}$ innymi, zarządzanie pracą i pozyskiwanie informacji. Nowe technologie zwiększają szybkość reakcji i redukują czas przeznaczony na komunikacje. Strumienie informacji płynące w czasie rzeczywistym sprawiają, że Internet staje się bardziej atrakcyjny niż tradycyjne media. Ponadto analizując przyczyny wchodzenia jednostek i organizacji społecznych w sferę online wyraźnie rysują się potrzeby związane z komunikacją między ludźmi, zarówno wewnątrz organizacji, jak i z otoczeniem społecznym. Coraz częstszym narzędziem kontaktów są portale społecznościowe, zwłaszcza popularny serwis Facebook.com oraz mikro blog Twitter. Dzięki tym interaktywnym sieciom tworzona jest ciągła komunikacja z otoczeniem społecznym.

Światowym propagatorem przedsięwzięć w Sieci jest Simon Mainwaring, założyciel organizacji konsultingowej doradzającej firmom i organizacjom pozarządowym jak poprzez media społecznościowe budować zarówno wspólnotę i zyski. W swojej najnowszej książce We First opisuje w jaki sposób organizacje pozarządowe budują w Sieci świadomość, tworzą więzi i zbierają fundusze niezbędne do funkcjonowania organizacji [Mainwaring 2011: 23]:

1. Zdaniem autora $w$ dzisiejszych realiach rynkowych Facebook jest jednym $z$ najlepszych miejsc dla organizacji obywatelskich na odkrycie i skontaktowanie się z większą grupą odbiorców. Organizacja pozarządowe zakładając swoją stronę na portalu Facebook budują rozległe sieci kontaktów i znacznie zwiększają widoczność swojej działalności, której nie sposób osiągnąć w takiej skali za pomocą żadnych innych mediów.

2. Serwisy społecznościowe są wszechobecne, niedrogie (w porównaniu do innych mediów), i dostępne przez całą dobę. Pozwala to organizacjom non-profit na wykorzystanie sieci o każdej porze dnia, co pozwala na szerszy zasięg treści, i daje większe szanse na budowania społeczności lub zwiększenia funduszy.

3. Osobisty charakter więzi w owych mediach ułatwia wzbudzanie empatii, zaangażowania i zwiększania zasięgu działania organizacji pozarządowych.

4. Facebook umożliwia budowanie interakcji między beneficjentami a darczyńcami, przez co kampanie są o wiele skuteczniejsze. Działa 
tu również prosty psychologiczny mechanizm, w myśl którego, im więcej dajemy od siebie, tym bardziej jesteśmy zaangażowani.

5. Kampanie na portalu Facebook wzmacniają wizerunek marki. Dzięki temu organizacje stają się bardziej rozpoznawalne i skuteczne.

Profile i strony w Internecie spełniają zatem szereg funkcji. Do najczęstszych aktywności na portalach społecznościowych należy zaliczyć tworzenie sieci sympatyków, między innymi: organizacji, ruchu, partii, reformy, pomysłu. Przyłączanie się do konkretnej grupy w sieci może być wyrazem współodczuwania sympatii, czy przynależności do organizacji w realnym życiu. Na łamach mediów społecznościowych organizacje tworzą również swoisty „newsletter” gdzie można odnaleźć bieżące informacje o interesującej go organizacji, obejrzeć najnowsze posty, zdjęcia, relacje $\mathrm{z}$ ważnych wydarzeń lub wysłać wiadomość. Obserwatorzy profili piszą komentarze, wyrażając swoje poparcie bądź dezaprobatę. Przeniesione do Sieci dyskusje przybierają różne formy. Od prostej wymiany zdań i popierania idei poprzez rozpowszechnianie i publiczną aprobację danej sprawy, po wielowątkowe dyskusje toczące się na forach internetowych i grupach dyskusyjnych. Dzięki szeroko zakrojonym akcjom, organizacje stwarzają środowisko społeczne przyjazne swojej działalności i włączają się w szeroko pojętą internetową sferę publiczną. Dodatkowo klasyczna przestrzeń publiczna funkcjonuje coraz słabiej. Jest to skutek rozwoju nowych technologii komunikacyjnych odrywających stosunki i relacje między ludźmi od konkretnego terytorium. „Małe i trwałe wspólnoty z ograniczoną grupą znaczących innych są zastępowane przez rozległy i wciąż rozszerzający się wachlarz interakcji dokonywanych w cyberprzestrzeni" [Nowacki 2011: 7].

Wątpliwości dotyczą tego, czy mamy do czynienia z prawdziwym dyskursem społecznym. Portale stały się bowiem miejscem chętnego eksponowania poglądów i wspierania inicjatyw przez prywatnych użytkowników, które nie zawsze łączą się z przenoszeniem aktywności i dyskusji w sferę niemedialną. Tomasz Masłyk słusznie zauważa, że Internet i towarzyszące mu technologie są czynnikiem koniecznym, ale niewystarczającym do budowania silnej demokracji opartej na deliberatywnych zasadach. Łatwo jednak - biorąc pod uwag jego możliwości - ulec przekonaniu o jego sile i mocy sprawczej w oddziaływaniu na formę i treść działań społecznych. Tymczasem należy pamiętać o tym, że Internet jest jedynym narzędziem, które może w istotny sposób wzmacniać i promować aktywność obywatelską, a także skłaniać do udziału w procesie deliberatywnego - racjonalnego dyskursu politycznego [Masłyk 2007: 265]. Szczególnie istotny wydaje się być w małych społecznościach, gdzie daje możliwość oderwania swoich 
wypowiedzi i działań od pełnionych w środowisku społecznym ról i oczekiwań. „Ze względu na nakładanie się w małych społecznościach relacji (np. urzędnik jest jednocześnie sąsiadem, dalekim kuzynem, kolegą z podstawówki itd.), interesujący jest potencjał technologii do formalizowania stosunków, a także ich anomizacji, która może ułatwiać podejmowanie merytorycznych dyskusji” [Technologie dla III sektora... 2011].

Internet pozwala również na poruszanie tematów, o których milczą inne media. Na łamach poszczególnych grup na portalu Facebook.com można przeczytać o karze śmierci w Iranie (np. „I bet I can find 1.000.000 Against Government Violence in Iran” albo „In Defense of Freedom of Speech in Iran") zamieszkach w Palestynie albo poszukać kontrowersyjnych, nieoficjalnych opinii o katastrofie w Smoleńsku. Dyskusje toczą nie tylko wśród zwolenników jakiegoś poglądu, ale również między oponentami, zwłaszcza jako reakcja na posty czasopism, dzienników, publicystów. Często dochodzi do niezamierzonej konfrontacji poglądów na profilach osób, które posiadają w gronie znajomych internautów o innych zapatrywaniach. Dzięki nowym technologiom czasami wystarczy jeden post, by wzbudzić silny rezonans wśród internautów. Na przykład, z pozoru nieznaczący gest nastoletniej dziewczyny Polski, która założyła grupę na Facebooku o nazwie „Mówię stanowcze nie zburzeniu Pałacu Kultury” w ciągu zaledwie dwóch tygodni jej zebrał ponad 8 i pół tysiąca „fanów”, a po pół roku istnienia w Sieci (dane z kwietnia $2010 \mathrm{roku}$ ), ponad 17 i pół tysiąca ${ }^{1}$. Dzięki szybkiemu tempu rozpowszechniania się informacji, grupy te stanowią silne zaplecze mobilizacyjne i czynią Internet podstawowym narzędziem komunikacji.

Pozyskiwanie nowych sympatyków, aktywistów i budowanie kapitału społecznego to cele, które możemy osiągnąć budując rozległe sieci kontaktów w Internecie. Współczesne kontakty wirtualne i łączenie się w grupy odpowiada na najbardziej pierwotną ludzką potrzebę przynależności do grupy. Zmiana dystansu między odbiorcą a nadawcą treści, łatwość w nawiązywaniu kontaktów i budowania dialogu sprzyja budowaniu kapitału społecznego wokół organizacji bądź ruchu społecznego. Jedną z najbardziej znanych definicji kapitału społecznego sformułował Robert Putnam, mówiąc, że zjawisko to odnosi się do „cech społecznego zorganizowania, takich jak sieci, normy i społeczne zaufanie, ułatwiających ku obopólnej korzyści koordynację i współpracę" [Putnam 1996: 17]. Suma naszych kontaktów w mediach społecznościowych ma bardzo duży potencjał do

https://www.facebook.com/pages/M\%C3\%B3wi\%C4\%99-STANOWCZE-NIE-zburzeniu-Pa \%C5\%82acu-Kultury/177880161305, [19.11.2012]. 
rozrastania się i tworzenia nowych sieci. Dodatkowo wiele internetowych projektów społecznych zmienia swą strukturę, znacznie się decentralizując. Coraz częściej mamy do czynienia z wielowektorową współpracą, dzieleniem się wiedzą, gdzie koordynacja przebiega bez tradycyjnych hierarchii organizacyjnych oraz bodźców rynkowych. Zjawisko sieciowej współpracy wokół wspólnego celu bądź dóbr analizuje Yochai Benkler, określając je terminem sieciowego zaangażowania, który może być szczególnie ważny przy analizie Internetu. Opisuje on sytuację, w której mała grupa ludzi, szczególnie oddana projektowi nadzoruje działania wszystkich uczestników ruchu - tych przypadkowych i tymczasowych, ale też tych regularnie zaangażowanych [Danielewicz 2010: 127-130]. Co więcej, co zauważa Michał Danielewicz w swoich pracach na temat Wikipedii, większość badaczy twierdzi, że systemy społeczne oparte na słabych więziach są niefunkcjonalne, natomiast fenomen Wikipedii ukazuje odwrotną sytuację. Sprowadzając rzecz z poziomu systemu do poziomu organizacji i rozważając zależność w drugą stronę można zaryzykować stwierdzenie, że w przypadku Wikipedii o jej sukcesie (dynamika i rozwój organizacji) zdecydowało oparcie się wyłącznie na więziach słabych [Danielewicz 2010: 130]. Dariusz Niedźwiedzki [2009: 2] na łamach "Tygodnika Powszechnego” posługiwał się pojęciem „obywatela ad hoc”, który pomaga z doskoku, nie angażując się $\mathrm{w}$ formalne struktury organizacji i w związku $\mathrm{z}$ tym nie widnieje często w statystkach jako aktywny społecznie obywatel. Mimo tego wykonuje niejako „z doskoku” wolontariat, formalnie nie przynależąc do żadnej organizacji. Wiele przejawów takiej aktywności można zauważyć w Internecie. Istnieją bowiem liczne grupy samopomocowe, Wikipedyści, tłumacze oraz cyberwolontariusze $\mathrm{z}$ wielu innych dziedzin.

Następną kwestią, którą ułatwiają rozlegle sieci i media społecznościowe są wydarzenia międzynarodowe. Nigdy wcześniej informacje nie rozprzestrzeniały się tak szybko, jak za sprawą Internetu. Co więcej, odrzucając bipolarny model dzielący rzeczywistość na to co globalne i lokalne, możemy wyodrębnić nowe zjawisko zwane przez Saski Sassen [1998] z Columbia Univeristy zwielokrotnioną lokalnością (multiple localism), tworzoną $\mathrm{w}$ rezultacie powiązania w globalną sieć jednostek i instytucji działających lokalnie. Zdaniem autorki bez telekomunikacji i jej szeroko rozumianych usług nie jest możliwa działalność w skali ponadlokalnej. Nowa technologia ułatwia powstanie międzynarodowych ruchów społecznych, sojuszy i grup samopomocowych, które wymieniają się doświadczeniami. W rezultacie ich pozycja staję się silniejsza i mocniej ustrukturalizowana, co daje możliwość większego oddziaływania, z pominięciem struktur lokalnych, narodowych 
lub międzynarodowych. Nowe media stają się zatem narzędziem, które pomaga uwolnić się od dyktatu głównych sił finansowych i politycznych, a zarazem przeciwdziałać wykluczeniu społecznemu.

\section{Kampanie społeczne i kampanie polityczne}

Nowe technologie informacyjne niosą w sobie olbrzymi potencjał demokratyczny. Rozszerzają sferę publicznej komunikacji, wzmacniają głos jednostek i grup społecznych, zwiększają transparentność, ograniczają wpływ władzy na życie społeczne, zacierają tradycyjne hierarchie, ułatwiają samoorganizację i ewentualną eskalację protestu. Internet sprawia, że polityka staje się sferą naturalnej aktywności - dalece częstszą niż okazjonalne uczestnictwo w wyborach. Sieć diametralnie zmieniła zasady gry politycznej, zarówno na poziomie rywalizacji międzypartyjnej, jak i dwukierunkowej relacji między politykiem a obywatelem. Politycy i partie polityczne zaczęły wykorzystywać Internet jako oczywistą platformą przekazu, reklamy, kształtowania wizerunku. Nowa platforma umożliwia ciągłe i nielimitowane docieranie z przekazem do obywateli, a obywatelom komentowanie, ocenianie i weryfikowanie informacji. Co ważne, odbywa się to bez pośrednictwa mediów tradycyjnych, które obecnie często są bezpośrednimi uczestnikami procesów politycznych. Internet ze swojej istoty jest egalitarny, zatracają się tu tradycyjne hierarchie a często też normy społeczne i obyczajowe. W Sieci polityk staje się zwykłym uczestnikiem dyskusji, narażonym na ataki oraz oceny. Społeczność internetowa bezlitośnie wytyka pomyłki, weryfikuje przekaz, oddziela prawdę od propagandy - jest to proste, ponieważ Sieć to także nieprzebrana skarbnica wiedzy $\mathrm{i}$ informacji. Internet w znacznym stopniu wypełnia obecnie rolę czwartej władzy, zastępując w tym media tradycyjne. Te coraz bardziej odchodzą od ideału bezstronności. Przyjmują wyraźne nastawienie ideologiczne, ustawiając się po określonej stronie sporu politycznego. Kontrolowane przez państwa, mające swoje interesy grupy kapitałowe czy partie polityczne tracą niezależność. Rolę niezależnych dziennikarzy wypełniają natomiast blogerzy, którzy sami decydują o publikowanych przez siebie treściach. Współcześni blogerzy aspirują do odgrywania roli prawdziwego, niezależnego "głosu ludu”. Ich przekaz ma być alternatywą do przekazu serwowanego przez upolitycznione media tradycyjne. Dużą zaletą tego typu twórczości jest stała interakcja z czytelnikiem, który może poniekąd współuczestniczyć w tworzeniu przekazu. Blogi, poza kilkoma wyjątkami, są jednak nadal publicystyką niszową o dalece mniejszym autorytecie 
i możliwości oddziaływania na opinię publiczną niż dziennikarstwo mediów tradycyjnych.

Istotną wartością Internetu jest to, że potrafi skłonić do zabrania głosu jednostki, które dawno odeszły od zainteresowania polityką w jej tradycyjnej formie. W Sieci prowadzone są zbiórki podpisów pod różnymi apelami, propozycjami legislacyjnymi czy petycjami. Angażują one niekiedy dziesiątki tysięcy internautów. Internet pozwala na swobodne wypowiadanie się w codziennych kwestiach otaczającej rzeczywistości - dziurawych ulic, braku chodnika, miejsc w żłobku itd. każdy może wrzucić do sieci fotografię ilustrującą problem w najbliższym otoczeniu. Rozszerza to wydanie sferę aktywności obywateli, którzy w realnym świecie często nie zdobyliby się na protest, komentarz czy interwencję. Sprawia, że decydenci są poddawani stałej kontroli i monitoringowi własnych działań. W Sieci łatwiej jest walczyć o transparentność z organami administracji i władzy, które z reguły niechętnie dzielą się informacjami, obywatele mogą uczestniczyć w tworzeniu katalogów spraw istotnych w swoim otoczeniu, współdecydować o miejskich inwestycjach, informować o problemach. Dzięki powszechnemu dostępowi do Sieci możliwy będzie realny udział obywateli w decyzjach politycznych zarówno w mikroskali, jak i w makroskali. Rozszerza się w ten sposób zakres współrządzenia [Bendyk 2011b]. Głosowanie przez Internat w wyborach czy referendach może zmodernizować naszą demokrację i ożywić procesy demokratyczne, dać obywatelowi większą podmiotowość i poczucie wpływu na bieżące rozstrzygnięcia. Jak dotąd instytucję e-wyborów rozbudowała tylko Estonia, jednak wydaje się, że ten typ głosowania, po wyeliminowaniu ewentualnych zagrożeń i problemów będzie tendencją już w nieodległej przyszłości. W tym kontekście pojawia się pytanie czy dzięki nowym technologiom informatycznym ludzie stają się bardziej otwarci społecznie i politycznie, czy też przeciwnie - instynktownie poszukują potwierdzenia w sieci swoich własnych poglądów i zapatrywań politycznych. Wydaje się, że pomimo swojej otwartości Internet jest tylko odzwierciedleniem świata rzeczywistego $\mathrm{z}$ jego podziałami, sympatiami i antypatiami. $\mathrm{W}$ tym zakresie Internet jest bardziej formą organizowania się rozproszonych zwolenników partii czy określonych ideologii, niż miejscem poszukiwań nowych rozwiązań. Znacznie lepiej sprawdza się w kwestii aktywności społecznej, którą Internet zarówno inspiruje jak i dynamizuje, dając każdemu do ręki narzędzie wpływu na otoczenie.

Internet to również reguły gry, które nie zawsze są w pełni akceptowalne przez polityków - szczególnie tych posiadających władzę. Trudno 
go kontrolować, manipulować, zawłaszczać, korumpować. Co prawda są prowadzone tego typu działania, jednak zawłaszczenie przez jakiś reżim całej Sieci wydaje się nierealne. Dzięki Internetowi polityka toczy się dziś na bieżąco, online. Politykom brakuje czasu na przygotowanie odpowiedniej reakcji. Zmusza to ich do działań spontanicznych kończących się niekiedy przeróżnymi passusami. Również odbiorcy komunikatów politycznych mogą uczestniczyć w polityce przebiegającej w czasie teraźniejszym. Nie muszą, jak niegdyś, czekać na poranne wydanie prasy, żeby przeczytać o wydarzeniach, nie muszą nawet czekać na reakcję polityków na wydarzenia transmitowane na żywo. Polityka dociera dziś do internauty równolegle z przebiegiem zdarzeń. Gorące komentarze w mediach społecznościowych często wnoszą więcej informacji, niż przygotowywane i reżyserowane konferencje prasowe. Nieprzewidywalność Internetu sprawia, że istnieje stała pokusa, żeby w jakiś sposób kontrolować treści w Sieci. Co ciekawe, dzieje się tak nie tylko w państwach niedemokratycznych, ale nawet w utrwalonych demokracjach. Czasem są nawet podejmowane próby kontroli czy cenzury zawartości Sieci jednak z reguły okazują się one nieskuteczne, a nawet uderzają rykoszetem w samych inicjatorów tego typu akcji. Internet potrafi szybko stworzyć potężną sieć sprzeciwu, co pokazały między innymi protesty w sprawie ACTA na początku 2012 roku. Niemniej cały czas toczy się dyskusja nad zakresem wolności słowa w Sieci. Zapadają wyroki skazujące za publikowane w Internecie treści.

Sieć to dwa strumienie informacji. Pierwszy wytwarzany przez władzę polityczną, administrację państwową i instytucje. Drugi, wytwarzany przez samych obywateli, niezależny od władzy, często jej wrogi, trudny do kontrolowania i z tego względu nieprzewidywalny. Nawet w państwach niedemokratycznych takich, jak Arabia Saudyjska, Iran, Korea Północna, Chiny, Rosja, czy Białoruś kontrola Internetu nie jest do końca skuteczna. Fascynacja możliwościami politycznymi Internetu wzrosła po szeregu protestów i rewolucji w państwach arabskich [Bendyk 2011a], Mołdawii, Rosji czy na Białorusi, gdzie platformą organizacji społeczeństwa były portale społecznościowe. Trzeba jednak zaznaczyć, że prawdziwe rewolucje nie toczyły się w Internecie, ale na ulicach. Internet był istotnym narzędziem $\mathrm{w}$ walce $\mathrm{z}$ reżimami, jednak przyczyny protestów miały swoje źródło $\mathrm{w}$ realnej polityce prowadzonej przez władze. Internet był zresztą wykorzystywany także przez reżimy przeciwko ruchom demokratycznym. W Iranie podczas twitterowej rewolucji bardzo skutecznie działało coś w rodzaju sieciowego ORMO, które wyłapywało w sieci fotki i personalia protestujących [Bendyk 2011a]. System kontroli, a przed upadkiem blokady Sieci 
wprowadził Kadafi w Libii. W Rosji reżim utrzymuje 600 osobową armię „cyberżołnerzy”, którzy w sieci dbają o pozytywny wizerunek władzy [Cyberżołnierze...]. Ich komentarze zalewają nie tylko rosyjski, ale też światowy Internet. Moskwa bardzo starannie przygotowuje się do globalnej rywalizacji w Sieci, która jest istotnym elementem tak zwanej wojny hybrydowej [Darczewska 2014].

Internet to bardzo specyficzne i istotne narzędzie, jeśli próbuje się zbudować platformę protestu, kontestacji, sprzeciwu, a znacznie trudniejsze w budowaniu niespontanicznego poparcia. Jak pokazuje przykład Roh Moo-hyeona, który w 2002 roku wygrał wybory prezydenckie w Korei Południowej prowadząc kampanię głównie w Internecie [Huh In-hae b.d.], budowa pozycji politycznej opartej na Sieci jest możliwa. Bardzo aktywną i jednocześnie nowatorską kampanię w Sieci prowadził Barack Obama w 2008 roku. W Polsce z Internetem wiąże się sukces Kongresu Nowej Prawicy w wyborach do Europarlamentu 2014 roku. W tym przypadku okazało się, że na kontestacji establishmentu można w Sieci zbudować pewne poparcie. Zastrzec jednak trzeba, że Janusz Korwin Mikke prowadził kampanię nie tylko w Internecie - chociaż było to dominujące medium, i uzyskał ograniczony sukces z powodu bardzo niskiej frekwencji wyborczej. Wydaje się, że Internet może być pomocny w kształtowaniu pozytywnego wizerunku, jednak absolutnie nie jest jeszcze w stanie zastąpić tradycyjnych mediów w kwestii reklamy wyborczej.

\section{Zagrożenia. Czy powinniśmy się bać Internetu?}

Istnieje coraz więcej głosów na temat szkodliwego oddziaływania Internetu. Nie dzieje się tak przypadkowo. Wiele negatywnych skutków może zauważyć nawet najmniej wnikliwy obserwator. Na ich czele wyróżnia się zjawisko uzależnień, manipulacji i prowizorycznego sprawstwa społecznego. Ma to szeroki wpływ na kształt sfery publicznej.

Internet daje nam poniekąd fałszywe odczucie, że wpływamy na otaczającą nas rzeczywistość przez szeroko zakrojone działania w Internecie. Jednak, jak zauważają Bernard Manin i Azi Lev-On [2009: 113], Internet jako medium stanowi mieszane błogosławieństwo. $Z$ jednej strony, grupy te są idealnym miejscem dla użytkowników o podobnych poglądach, w których istnieje wysokie ryzyko zmniejszenia dyskusji i zignorowanie przeciwstawnych punktów widzenia”. Dodatkowo siła oddziaływań kliknięć, petycji aprobacji pomysłów w Sieci, nie jest wystarczająca do dokonania gruntownej zmiany społecznej. Wydaje się, że przeciętny Internauta 
coraz częściej tego nie zauważa. Internetowi aktywiści tworzą niezliczone ilości treści, które mają swoją rolę informacyjną bądź propagandową, ale nie zastąpią realnych działań poza rzeczywistością wirtualną. Iluzja działania sprawia, że wiele aktywności rozmywa się Sieci, spełniając jedynie funkcje informacyjne i wizerunkowe. Znane w telewizji, zjawisko zippingu [Chateau 1997], czyli szybkiego przeskakiwania z kanału na kanał, jest jeszcze bardziej intensywne w Sieci. Zwłaszcza w portalach społecznościowych, wiele różnorodnych treści zlewa się ze sobą i pojawia jednocześnie. Umysł stara się je selekcjonować, ale przez niezliczony wybór nie jest w stanie skoncentrować się na tych wartościowych.

Dodatkowo istnieje ryzyko polaryzacji poglądów. Dzieje się to dzięki możliwości wyrywkowego śledzenia nadawanych treści. W rzeczywistości wirtualnej każdy użytkownik może selekcjonować zarówno kanały informacyjne, jak i otaczającą go społeczność internetową. Nierzadko dochodzi do sytuacji, w której internauta skupia wokół siebie jedynie te źródła informacji, które odpowiadają jego wcześniejszym założeniom. Dzięki tym, często nieświadomym, zabiegom „otwarty i różnorodny Internet” może okazać się w rzeczywistości zamkniętą hybrydą światopoglądową. Spersonalizowane otoczenie sieciowe daje poczucie przynależności do szerszej grupy społecznej i umacnia istniejące poglądy. Wtedy szanse na zmianę poglądów są minimalne. Dochodzi do polaryzacji wcześniejszych założeń i ciągłego surfowania $z$ dala od poglądów odmiennych od własnych.

Innym wypaczeniem demokracji są liczne manipulacje. Wojciech Orliński [2013] w swojej książce Internet. Czas się bać opisuje procedury codziennej inwigilacji. Zdaniem autora nigdy wcześniej przepływ informacji, korespondencji czy pieniądze nie był tak łatwy do skontrolowania. Dodatkowo Sieć nie jest, zdaniem Orlińskiego, przestrzenią demokratyczną. Każdy użytkownik portalu bądź witryny może być bowiem bez podania przyczyny zablokowany bądź kompletnie wyrzucony [Orliński 2013: 55]. Tego samego zdania jest Julian Assange, australijski aktywista internetowy znany zzaangażowania w WikiLeaks ${ }^{2}$, który w książce Cypherpunks. Wolność $i$ przyszłość Internetu [Assange, Appelbaum, Muller-Maguhn, Zimmermann 2013], opisuje dwa z pozoru wykluczające się cechy Internetu, który daje wolność, a jednocześnie ją zabiera. Sieć w coraz mniejszym stopniu jest przy tym przestrzenią anonimową. Przeciwnie, Internet, zbiera i przecho-

2 WikiLeaks - serwis internetowy pozwalający na anonimowe publikowanie dowodów działań niezgodnych z prawem. Zawiera on zbiór nielegalnie wykradzionych dokumentów rządowych i korporacyjnych. 
wuje o nas coraz więcej danych, coraz głębiej potrafi też określić nasz profil i preferencje.

Przykładem psychologicznego ograniczania wolności jest trolling, który ma na celu zmienić obraz internetowych komentarzy, przez generowanie sztucznych postów i sprawić wrażenie, że przeciwnicy są w mniejszości. Jednym z głównych celów owych zabiegów jest osiągnięcie kolejnego efektu - efektu spirali milczenia, która wynika z fałszywego przekonania, że jest się w mniejszości. Jeżeli ostatni (fałszywie) uwierzą w to, będą mniej chętnie się wypowiadać, a grupowe przekonania będą powoli zmieniały się, na korzyść tych członków, którzy (fałszywie) wierzą, że przebywają w większości [Bachmann, Lyubashenko 2014]. „Taki efekt można wzmocnić, jeżeli wpływowe, elitarne media wprowadzą wrażenie, iż opinia mniejszości jest opinią większości. Później opinia mniejszości może stać się opinią większości tylko dlatego, że wystarczająco dużo ludzi uwierzyło, iż jest to opinia znacznej liczby osób, co z kolei zaczęło wpływać na ich myślenie" [Bachmann, Lyubashenko 2014].

Kolejnym zagrożeniem płynącym z Internetu jest stosunkowo duża łatwość manipulowania informacją przez państwo. a w konsekwencji także nastrojami społecznymi. Stąd pojawiające się wciąż nowe pomysły blokowania niewygodnych dla władzy treści czy w skrajnych przypadkach jak planuje się w Rosji - stworzenie narzędzi odcięcia kraju od globalnej Sieci. Oficjalnie Moskwa pragnie zabezpieczyć się przed potencjalnymi cyberatakami, ale faktycznie może chodzić o utrudnienie czy zablokowanie swobodnego przepływu informacji. Zabronione ma też zostać korzystanie z zagranicznych serwerów DNS dla domen RU i RF. W Rosji od 2008 roku działa wyspecjalizowana agencja Roskomnadzor ${ }^{3}$ tworząca i zarządzająca "rejestrem stron zakazanych”. Blokowanie stron znajdujących się na rejestrze jest od 2012 roku obowiązkowe dla wszystkich dostawców Internetu na terenie Rosji [Постановление... 2012]. W Chinach funkcjonuje tak zwana Złota Tarcza znana też jako The Great Firewall of China, która umożliwia rządowi filtrowanie wyników wyszukiwania i blokowanie słów i stron internetowych uważanych za niepożądane przez funkcjonariuszy Chińskie Biuro Kontroli Internetu [Chen 2014]. Firmy, które chcąc świadczyć usługi internetowe w Chinach muszą zgodzić się na stawiane przed nimi warunki, m.in. na trzymanie wszystkich danych chińskich użytkowników Sieci czy wydawanie władzom adresów IP.

3 Federalna Służba ds. Nadzoru w Sferze Łączności, Technologii Informacyjnych i Komunikacji Masowej, http://eais.rkn.gov.ru, [28.12.2018]. 
W Internecie toczy się dziś swoista wojna informacyjna. Przybiera ona inny charakter niż $\mathrm{w}$ tradycyjnych mediach. Pozbawiona moderacji jest często bardziej brutalna, bezpośrednio angażuje znaczne grono uczestników. W Internecie rozwija się też „dyskusja” za pomocą memów - żartobliwych rysunków komentujących bieżące wydarzenia. Ich rola jest dość istotna, ponieważ tego typu przekaz błyskawicznie dociera do bardzo szerokiej grupy odbiorców, nawet do ludzi zupełnie niezainteresowanych polityką. Może więc być używany jako broń „masowego rażenia” w „wojnach internetowych”. Innym rodzajem „broni” jest tworzenie przez rządy, partie polityczne, instytucje czy grupy społeczne stron internetowych, które „demaskują kłamstwa” przeciwników.

$\mathrm{W}$ tym momencie warto wspomnieć o tak zwanych watchdogach - organizacjach „strażniczych”, mających na celu obywatelskie monitorowanie poczynań władz publicznych i wypełniania obietnic przedwyborczych [Nowicki, Fialova 2000: 11]. Wiele z nich olbrzymią pracę wykonuje w Sieci. W Polsce działa m.in. Sieć Obywatelska Watchdog, Antykorupcyjna Koalicja Organizacji Pozarządowych oraz wiele lokalnych fundacji i stowarzyszeń. Ciekawy obraz jak może wyglądać obywatelska kontrola polityków wypowiadających się online, prezentuje działający w Stanach Zjednoczonych portal "Politwoops" ${ }^{4}$, który gromadzi Tweety polityków, które zostały przez nich wykasowane. Dzięki tej pomysłowej stronie, każdy może sprawdzić, jakie posty na portalu społecznościowymi, po pewnym czasie starali się ukryć jego autorzy. Wielkość zasobów i popularność strony dowodzi, że istnieją również pozytywne formy wykorzystania transparentności Internetu i aktywni obywatele mają szansę pewne formy zagrożeń i manipulacji minimalizować, a przynajmniej zdawać sobie z nich sprawę.

\section{Zakończenie}

Konwergencyjny charakter Internetu, zacierający granicę między odbiorcą i nadawcą sprawia, że staje się on coraz bardziej skomplikowanym polem badawczym. Szanse i zagrożenia jakie ze sobą niesie nie są łatwe do wychwycenia dla przeciętnego odbiorcy. Dodatkowo, zarówno negatywne i pozytywne skutki są w znacznej mierze uwarunkowane przez kapitał kulturowy, finansowy i społeczny internautów i twórców przekazu. „Same techniki komunikacyjne nie mają bezpośredniego wpływu na zwyczaje i praktyki kulturalne" [Goban-Klas 2006: 143]. W zależności

4 http://politwoops.sunlightfoundation.com, [28.01.2015]. 
od czynników społecznych, politycznych, a również kulturowych i ekonomicznych aktywność społeczna i polityczna w Internecie przybiera cały wachlarz metod budowania wirtualnych kontaktów i form sieciowej relacji. Warto również podkreślić, iż opisane wyżej działania nie zawsze są praktykami powszechnymi.

Celem niniejszego artykułu było opisanie współczesnej sfery publicznej w przestrzeni wirtualnej. W analizie pokazano wiele aspektów przenoszenia sfery publicznej do Sieci oraz związane z tym korzyści i zagrożenia. Wydaje się, że główna fala rewolucji wirtualnej, która gruntownie przebuduje rzeczywistość społeczną i polityczną, jest jeszcze przed nami. Już dziś zmiany, w porównaniu nawet z poprzednią dekadą, są jednak tak głębokie, że powodują realne rozwarstwienie społeczne na swoiste „kasty” - ludzi aktywnych wirtualnie, okazjonalnie korzystających z Sieci i wykluczonych cyfrowo. Prawdopodobnie podział ten będzie się stopniowo zacierał, jednak przyszłe elity wpływu i opinii będą wywodziły się z grupy, która najaktywniej i najefektywniej będzie potrafiła korzystać z zasobów Sieci. W konsekwencji zacznie zanikać znaczenie wszelkich „przekaźników” i „rezonansów” informacji - starych mediów. Nie musi to jednak oznaczać zwiększenia demokratyzacji procesów politycznych i przejrzystości samej polityki. Możliwość dotarcia ze sprecyzowanym i bezpośrednim komunikatem do odbiorcy faktycznie zwiększa pole do nadużyć, manipulacji i stosowania technik socjotechniki. Powoduje też, że przeciętny użytkownik Internetu będzie w przyszłości bardziej bezbronny niż dziś, ponieważ globalna Sieć jest coraz bardziej kontrolowana przez polityków, a przez to przestaje stanowić alternatywę dla starych mediów. Kolejną kwestią, zapewne nieodległej przyszłości, będzie „digitalizacja” człowieka, instytucji, firm - sprowadzenie wszelkich podmiotów do przedmiotowego zapisu cyfrowego. Człowiek czy firma będą odbierani jako realny byt głównie przez swoją historię zapisaną w Sieci. Tą zaś stosunkowo łatwo manipulować, a w skrajnych przypadkach wymazać. Szczególnie groźny jest fakt, że sama specyfika Internetu, zwłaszcza tak zwanych mediów społecznościowych bardzo utrudnia weryfikowanie manipulacji i propagandy, oddzielenie prawdy od fikcji. Wiadomość wrzucona do Sieci zaczyna żyć własnym życiem. Rozprzestrzenia się, zwłaszcza jeśli sprawia wrażenie informacji „prawdziwej” na przykład powołującej się na „świadków”, „anonimowych informatorów”, czy korzystającej ze zdawałoby się niepodważalnych dowodów w postaci zdjęć czy filmów. Niestety, takie informacje są często preparowane, a obrona przed tego typu manipulacjami jest niezwykle trudna. Istotnym problemem współczesnej sieci jest także 
język w Internecie - dużo brutalniejszy od tego w mediach tradycyjnych. Użytkownicy Internetu stopniowo tracą też coś, co jest dziś jednym z fundamentów rozwoju sfery publicznej w Sieci - anonimowość.

Obecnie, doceniając wszelkie korzyści, które przynoszą nowe media coraz głośniej mówimy jednak o zagrożeniach. Sieć powinna być istotnym elementem rozszerzającym sferę publiczną, ułatwiającą komunikację, dostęp do wiedzy i informacji, ale przenoszenie kolejnych segmentów życia społecznego w świat wirtualny dehumanizuje jednostkę i społeczeństwo, pozbawia je istotnych regulatorów relacji międzyludzkich, niszczy więzi, kulturę, brutalizuje komunikację, powoduje wyobcowanie człowieka. Sieć powinna być środkiem ułatwiającym poruszanie się w realnym świecie, nie powinna być jednak dla niego alternatywą.

\section{Bibliografia}

Arendt H. (2010), Kondycja ludzka, Warszawa,

Assange J., Appelbaum J., Muller-Maguhn A., Zimmermann J. (2013), Cypherpunks. Wolność i przyszłość Internetu, Gliwice,

Bachmann K., Lybashenko I. (2014), Czy rosyjska kampania propagandowa w Internecie jest skuteczna?, https://wszystkoconajwazniejsze.pl/klaus-bachmann-igor-lyubaszenko-czy-rosyjska-kampania-propagandowa-w-internecie-jest-skuteczna, [28.12.2018].

Bendyk E. (2011a), Wyklikane rewolucje, „Polityka”, nr 11.

Bendyk E. (2011b), Polityk.małpa.pl, „Polityka”, nr 25.

Borowski H., Wiśniewska M. (2011), Technologie dla III sektora i społeczności lokalnych. Raport z badania, Warszawa.

Castells M (2010), Społeczeństwo sieci, Warszawa.

Chateau D. (1997), Efekt zappingu, [w:] A. Gwóźdź (red.), Pejzaże audiowizualne. Telewizja. Wideo. Komputer, Kraków.

Danielewicz M. (2010), Wikipedia - socjologiczny reportaż z miejsca zdarzeń, „Studia Socjologiczne", nr 2.

Goban-Klas T. (2006), Media i komunikowanie masowe. Teorie i analizy prasy, radia telewizji i Internetu, Warszawa.

Darczewska J. (2014), Anatomia rosyjskiej wojny informacyjnej. Operacja krymska-studium przypadku, „Punkt Widzenia”, t. 42, Warszawa

Chen L.Y. (2014), Breaking Through China's Great Firewall, http://www.businessweek.com/ articles/2014-03-20/secretive-web-activists-give-chinese-a-way-around-censorship, [15.01.2015].

Mainwaring S. (2011), We First. How Brands and Consumers Use Social Media to Build Better World, Nowy Jork. 
Manin B., Lev-On A. (2009), Happy accidents: Deliberation and online exposure to opposing views, [w:] T. Davies, S. Gangadharan (red.), Online Deliberation: Design, Research and Practice, Chicago

Masłyk T. (2007), Demokracje deliberatywna a Internet, [w:] M. Szpunar (red.), Media a polityka, Rzeszów.

Niedźwiedzki D. (2009), Obywatel ad hoc, „Tygodnik Powszechny”, nr 47 (dodatek: Jaka Polska - w jakiej Unii).

Nowacki G. (2011), Rachityczny sektor organizacji pozarządowych w ubogiej/martwej sferze publicznej, [w:] Raport z badań: Diagnoza organizacji pozarzadowych. Badanie socjologiczne w mieście Białystok i powiecie białostockich $w$ ramach projektu „Wsparcie funkcjonowania instytucji ekonomii społecznej-budowanie dobra wspólnego, Białystok.

Nowicki M., Fialova Z. (2000), Monitoring Praw Człowieka, Warszawa.

Orliński W. (2013), Internet. Czas się bać, Warszawa.

Putnam R.D. (1996), Blowing Alone, Malejacy społeczny kapitał Ameryki, „Res Publica Nowa", nr 6.

Sassen S. (1998), Globalization and its Discontents, Nowy Jork.

Постановление Правительства Российской Федерации от 26 октября 2012 г. № 1101: „О единой автоматизированной информационной системе. Единый реестр доменных имен, указателей страниц сайтов в информационно-телекоммуникационной сети «Интернет» и сетевых адресов, позволяющих идентифицировать сайты в информационно-телекоммуникационной сети «Интернет», содержащие информацию, распространение которой в Российской Федерации запрещено”.

\section{SUMMARY}

\section{New Information Technologies and the Public Sphere}

The last two decades have faced an intense, and in its essence - revolutionary, development of new information technologies, especially of the Internet, which fundamentally changes political, economic, and social life. The new situation that results from this Internet boom requires redefinition of a number of concepts, including the notion of "public sphere". The purpose of our work is to describe the contemporary public sphere in the context of the virtual space. The article opens with a framework of the concept of the public sphere, and a short historical outline of its twentieth-century theory. Then, the main trends in the Web activism are presented along with a brief description of social and political campaigns taking place in the virtual world.

KEYWORDS: Internet, internet activists, internet discourse, public sphere 